\title{
Oxygen-dependence of ACTH-stimulated aldosterone and corticosterone synthesis in the rat adrenal cortex: developmental aspects
}

\author{
E D Bruder ${ }^{1,3}$, A K Nagler ${ }^{1,2}$ and H Raff $^{1,2,3}$ \\ ${ }^{1}$ Endocrine Research Laboratory, St Luke's Medical Center, Medical College of Wisconsin, Milwaukee, Wisconsin 53215, USA \\ ${ }^{2}$ Department of Medicine, Medical College of Wisconsin, Milwaukee, Wisconsin 53226, USA \\ ${ }^{3}$ Department of Clinical Laboratory Sciences, University of Wisconsin, Milwaukee, Wisconsin 53211, USA \\ (Requests for offprints should be addressed to H Raff, Endocrinology and Metabolism, St Luke's Physician's Office Building, 2801 W. KK River Parkway, \\ Suite 245, Milwaukee, Wisconsin 53215, USA; Email: hraff@mcw.edu)
}

\begin{abstract}
The control of ACTH-stimulated steroidogenesis under decreasing levels of $\mathrm{O}_{2}$ is not fully understood. The purpose of this study was to examine the effects of decreased $\mathrm{O}_{2}$ in vitro on rat adrenocortical steroid synthesis at different stages of development. Of interest was the evaluation of the effect of low $\mathrm{O}_{2}$ on steroidogenesis during the stress hyporesponsive period of the neonate. Rats were killed at 7,14 , or 42 days of age, adrenals collected and capsules (zona glomerulosa, ZG) separated from subcapsules (zona fasciculata/reticularis, ZFR). Cells were dispersed and placed into glass vials each gassed with a different level of $\mathrm{O}_{2}\left(21,5,2,1\right.$, or $\left.0 \% \mathrm{O}_{2}\right)$. The entire steroidogenic pathway was analyzed by measuring ACTH-stimulated cAMP, corticosterone and aldosterone production during a $2 \mathrm{~h}$ incubation. In addition, the early (P450 scc) and late (P450c11 $\beta$ and P450 aldo) pathway activities were examined in the presence of cyanoketone. The $\mathrm{PO}_{2}$ for half-maximal activity $\left(\mathrm{P}_{50}\right)$ for aldosterone synthesis in ZG cells from 7- and 42-day-old rats was
\end{abstract}

approximately $28 \mathrm{mmHg}$ and $7 \mathrm{mmHg}$ respectively, indicating that cells from older rats were more resistant to inhibition by low $\mathrm{O}_{2}$. The $\mathrm{P}_{50}$ for cAMP production from the $\mathrm{ZG}$ was $\sim 14 \mathrm{mmHg}$ for both age groups. The $\mathrm{P}_{50}$ for corticosterone synthesis was $\sim 28 \mathrm{mmHg}$ and $<7 \mathrm{mmHg}$ in ZFR cells from 7- and 42-day-old cells respectively. The only enzyme activities affected by low $\mathrm{O}_{2} \quad(<35$ $\mathrm{mmHg}$ ) were $\mathrm{P} 450$ aldo and $\mathrm{P} 450 \mathrm{scc}$. Moderate decreases in $\mathrm{O}_{2}$ (from $\sim 150 \mathrm{mmHg}$ ) decreased aldosteronogenesis, possibly due to observed decreases in cAMP generation, but not due to decreases in steroidogenic enzyme activity (7-day-old). Severe decreases in $\mathrm{O}_{2}$ presumably inhibited P450 aldo through a direct effect on enzyme activity (both ages). P450 scc activity (including cholesterol transport) also seems to be decreased by very low $\mathrm{O}_{2}$ (7-day-old). These findings illustrate a novel developmental alteration in $\mathrm{O}_{2}$-regulated steroid production, and may have implications for neonatal health and disease.

Journal of Endocrinology (2002) 172, 595-604

\section{Introduction}

The adaptation to hypoxia involves an integrated response among different organ systems. The ability to adapt to hypoxic conditions depends on cardiovascular, respiratory, renal and endocrine responses (Friedman \& Fahey 1993, Thomas \& Marshall 1995). It is advantageous for an organism to minimize the fluid and salt retention that occurs during hypoxic exposure. This would be beneficial because it prevents the development of cerebral and pulmonary edema, conditions often observed during acute mountain sickness (Slater et al. 1969). A decrease in the mineralocorticoid aldosterone would lead to this desired natriuresis and diuresis. Although decreased plasma aldosterone levels have been demonstrated in a number of hypoxic models in vivo (Raff 1991), the exact cellular mechanism of this decrease has yet to be elucidated across species.

Previous studies utilizing bovine adrenocortical cells in vitro have found that hypoxia directly inhibits aldosterone synthesis (Raff et al. 1989). This inhibition occurred in the presence of known stimulators of aldosterone production, such as adrenocorticotropic hormone (ACTH), 3', $5^{\prime}-$ cyclic adenosine monophosphate (cAMP), potassium, and angiotensin II (AII) (Raff et al. 1989, Raff \& Kohandarvish 1990, Brickner et al. 1992). Subsequent studies in bovine cells found that aldosterone production was inhibited in proportion to decreases in $\mathrm{O}_{2}$ through inhibition of the aldosterone synthase enzyme (P450 aldo) (Raff \& Kohandarvish 1990, Brickner et al. 1992).

The effects of hypoxia on adrenocortical function have been examined in rats in vivo. Results have revealed that 
the rat zona glomerulosa $(\mathrm{ZG})$ is more resistant to acute changes in $\mathrm{O}_{2}$ in vivo than other species previously studied (Raff \& Roarty 1998). Chronic hypoxia in vivo in adult rats decreases the expression of specific adrenal steroidogenic enzymes (Raff et al. 1996). Furthermore, the rat adrenocortical response to hypoxia in vivo exhibits differences at various stages of development (Raff et al. 1996, Raff et al. 1999). These differences are the result of a period of relative insensitivity to stressful stimuli at the level of the adrenal cortex. Studies have shown that this stress hyporesponsive period occurs during the first three weeks of life, and that the magnitude and patterns of steroidogenesis vary with developmental age and are also stressor-specific (Walker et al. 1991). It appears that diminished ACTH and corticosterone responses during this period are not due to hypothalamic dysfunction; rather, they are due to decreased sensitivity to stimuli at the level of the pituitary and adrenal (Walker et al. 1986). Therefore, it would be of interest to examine $\mathrm{O}_{2^{-}}$ dependent adrenal steroidogenesis in vitro during this unique period of development.

The purpose of this study was to assess the effects of hypoxia on ACTH-stimulated steroidogenesis in vitro. Using an in vitro model allowed us to study aldosterone production in the absence of known inhibitory factors such as atrial natriuretic peptide (ANP) (Elliot \& Goodfriend 1986). We chose to study ACTH-stimulated steroid production because previous studies have shown that AII is not the primary controller of aldosterone synthesis in the 7-day-old rat (Feuillan \& Aguilera 1996). Our first aim was to determine whether rat adrenocortical cells studied in vitro would display a sensitivity to low $\mathrm{O}_{2}$ similar to that previously shown in bovine cells. The second aim of our research was to evaluate developmental differences in the adrenocortical response to hypoxia. This was carried out using cells from neonatal rats and from juvenile, weaned rats. The final aim of the study was to assess isolated components of the steroidogenic enzyme pathway during hypoxia in vitro in cells from rats of different ages.

\section{Materials and Methods}

\section{Cell preparation}

All experimentation was approved by the Institutional Animal Care and Use Committee of the Medical College of Wisconsin and St Luke's/Sinai Samaritan Medical Center. Timed-pregnant Sprague-Dawley rats (Harlan Sprague Dawley, Inc., Indianapolis, IN, USA; $n=42$ ) were obtained at 14 days gestation and maintained on a standard sodium diet (Richmond Standard 5001, Brentwood, MO, USA) and water ad libitum in a controlled environment (lights on, 0600-1800 h). Parturition usually occurred on the afternoon of gestational day 21 .

Lactating dams were maintained with their litters until the pups were of the desired age (7- and 14-days-old).
Rats to be studied at 42 days of age were weaned from the dam at 21 days and randomly separated into groups of 5 per cage. At the desired age, rats were decapitated, and adrenal glands were quickly removed and placed into ice cold Krebs-HEPES-calcium buffer. The adrenal capsules were then manually separated from the subcapsules and each was digested in collagenase $(4 \mathrm{mg} / \mathrm{ml}$, Worthington Biochemical Corp., Freehold, NJ, USA). This separation allowed for the study of both isolated ZG cells (capsules) and of zona fasciculata/reticularis (ZFR) cells (subcapsules). Each batch of cells was counted and assessed for viability by trypan blue exclusion, both before and after the experimental incubation period. The dispersed cells were then placed in fresh buffer containing bovine serum albumin $(1 \mathrm{mg} / \mathrm{ml}$, Sigma Chemicals, St Louis, MO, USA) at a concentration of 100000 cells $/ \mathrm{ml}$. Cells were always studied the day they were dispersed. The following numbers of animals were used for each separate experiment: 40 pups at 7 days of age, 30 pups at 14 days of age, and 20 weanlings at 42 days of age.

\section{Hypoxia in vitro (assessment of entire steroidogenic pathway)}

Buffer $(2 \mathrm{ml})$ was placed into 16 separate $10 \mathrm{ml}$ glass vials: eight vials for capsular cells and eight vials for subcapsular cells. Within each of these cell-type groups, two vials each were gassed with $21,5,1$, or $0 \% \mathrm{O}_{2}$. Within each gas mixture group, one vial received ACTH stimulation (20 ng/ml, Peninsula Labs, Belmont, CA, USA) and one vial did not (basal release). Therefore, for each experiment performed, the following comparisons were made: capsule vs subcapsule, 21 vs 5 vs 1 vs $0 \% \mathrm{O}_{2}$, and no ACTH vs ACTH. All incubations were performed in a shaker bath at $37^{\circ} \mathrm{C}$. Gases were allowed to equilibrate in the vials until the appropriate $\% \mathrm{O}_{2}$ was measured with an $\mathrm{O}_{2}$ electrode (Microelectrodes, Inc., Bedford, NH, USA). Cell suspensions were then added to the appropriate vials to a concentration of $50000 \mathrm{cells} / \mathrm{ml}$ and agitated for 1 minute. Samples were drawn directly from the vials with a syringe at different time points $(0$ (pre-ACTH) , 10, 20, 60 , and $120 \mathrm{~min}$ post-ACTH) and quickly centrifuged to separate cells from buffer. The $\% \mathrm{O}_{2}$ in the cell medium was monitored with the $\mathrm{O}_{2}$ electrode. The supernatants were transferred to new tubes and frozen at $-20{ }^{\circ} \mathrm{C}$ until further analysis. Additional sets of experiments were performed using $2 \% \mathrm{O}_{2}$ to complete the data set in cells from 42-day-old rats because of the interesting results obtained from initial experiments.

\section{Assessment of isolated steroidogenic enzyme activity}

The set up for these experiments was identical to that found above. Each of the 16 vials received cyanoketone $(10 \mu \mathrm{M}$, donated by Sterling Winthrop, Collegeville, PA, USA), a potent inhibitor of $3 \beta$-hydroxysteroid dehydrogenase $(3 \beta-\mathrm{HSD}$, the enzyme responsible for the 
conversion of pregnenolone to progesterone). The early and late steroidogenic pathways were thus dissociated which allowed the analysis of the activity of the ratelimiting enzymes.

Early pathway: P450 scc activity The mitochondrial side-chain cleavage enzyme, present in both the ZG and the ZFR, catalyzes the conversion of cholesterol to pregnenolone. Vials from both cell types under each gas concentration were stimulated with dibutryl-cAMP (3 mM, Sigma Chemicals, St Louis, MO, USA). Enzyme activity was assessed by measuring the concentration of accumulated pregnenolone in the cell medium at various time points. This approach is also dependent on endogenous substrate (cholesterol) transport into the mitochondria.

Late pathway: $\mathrm{P} 450$ aldo and $\mathrm{P} 450 \mathrm{c} 11 \beta$ activities The late pathway involves the conversion of progesterone to 11-deoxycorticosterone (by 21 OHase) in both zones. The next step in the rat $\mathrm{ZG}$ is the conversion of 11-deoxycorticosterone to aldosterone, catalyzed by P450 aldo. The conversion of progesterone to 11deoxycorticosterone is not rate-limiting. Therefore, $\mathrm{P} 450$ aldo activity was assessed by adding exogenous progesterone $(3 \cdot 2 \mu \mathrm{M}$, Sigma Chemicals, St Louis, MO, USA) and measuring the concentration of aldosterone in the cell medium over the $2 \mathrm{~h}$ incubation. P450c11 $\beta$ catalyzes the conversion of 11-deoxycorticosterone to corticosterone in the ZFR. Since 21 OHase activity is not rate limiting, we assessed P450c11 $\beta$ activity by adding progesterone as above and measuring corticosterone production.

\section{Hormone/cAMP assays}

The concentrations of aldosterone, corticosterone and pregnenolone were measured by previously described RIA protocols (Raff et al. 1986, Raff \& Chadwick 1986). The accumulation of cAMP in the cell medium was measured by RIA (Amersham, Piscataway, NJ, USA) as described previously (Matthys et al. 1998).

\section{Statistical analysis}

Data were analyzed by two-way analysis of variance for repeated measures and Duncan's multiple range test (SigmaStat 2.03). $P<0 \cdot 05$ was considered significant. Data are presented as means \pm S.E.M.

\section{Results}

Figure 1 shows ACTH-stimulated aldosterone production from isolated ZG cells as a function of time. Each panel corresponds to cells from a different age group. Aldosterone production from 7- and 14-day-old cells was

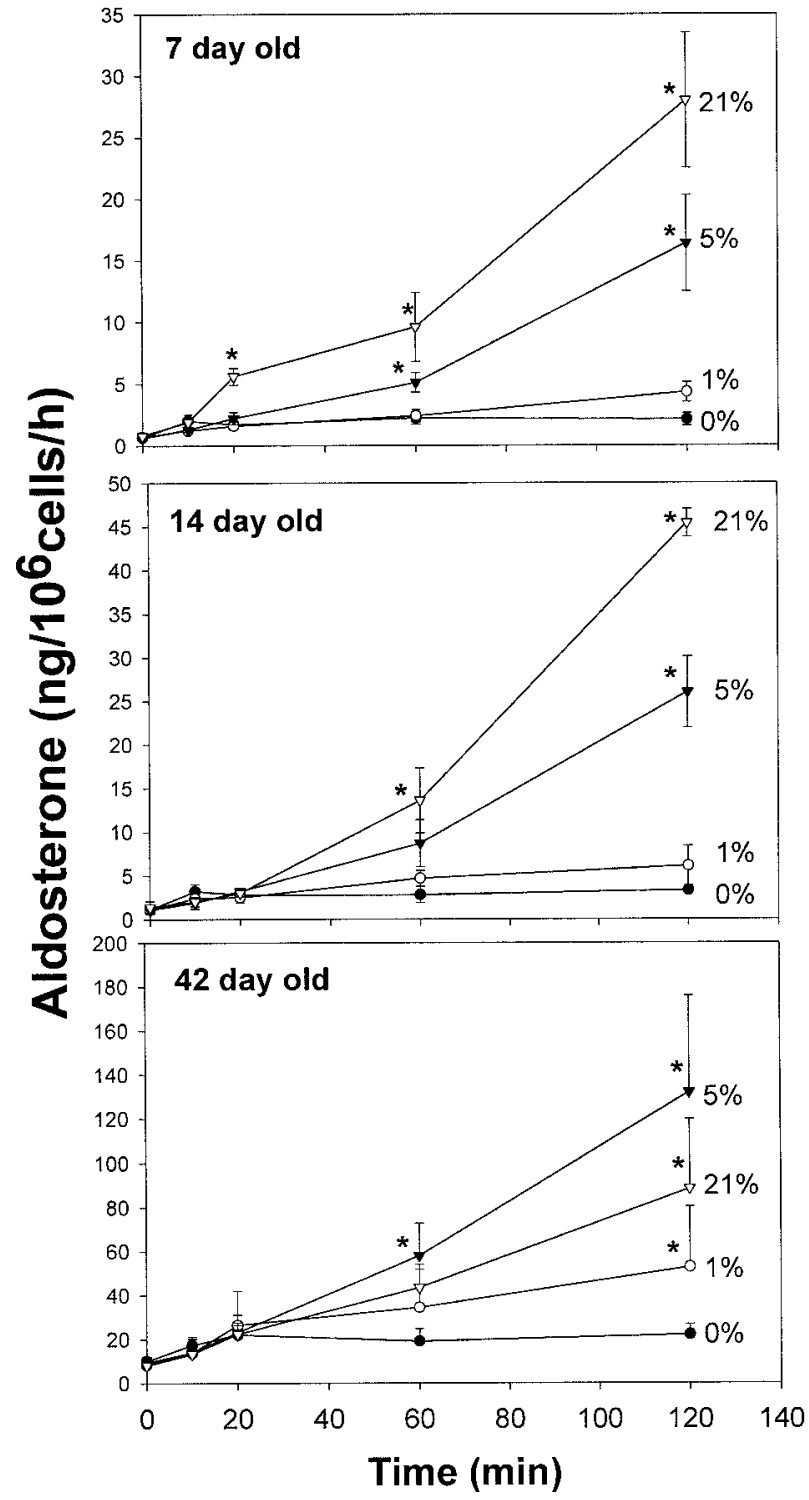

Figure $1 \mathrm{ACTH}$-stimulated aldosterone production from rat zona glomerulosa (ZG) cells exposed to decreasing levels of $\mathrm{O}_{2}$ as a function of time. ACTH $(20 \mathrm{ng} / \mathrm{ml})$ was added to the cell medium at $t=0$. Vertical lines above and below data points represent S.E.M. *Value significantly different from basal $(0 \mathrm{~min})$ value at the corresponding $\% \mathrm{O}_{2}$ with $P<0 \cdot 05$. Four separate experiments were performed for each age group.

inhibited by decreased $\mathrm{O}_{2}$ in a concentration-dependent manner. Five percent $\mathrm{O}_{2}(\sim 35 \mathrm{mmHg})$ resulted in a $40 \%$ decrease in aldosterone production whereas $1 \% \mathrm{O}_{2}(\sim 7$ $\mathrm{mmHg}$ ) resulted in an almost complete inhibition of aldosterone production after $120 \mathrm{~min}$ of incubation. Surprisingly, even at $0 \% \mathrm{O}_{2}$ there was some production of aldosterone, albeit small ( $8 \%$ of max). Aldosterone production from cells from 42-day-old rats was less sensitive to 


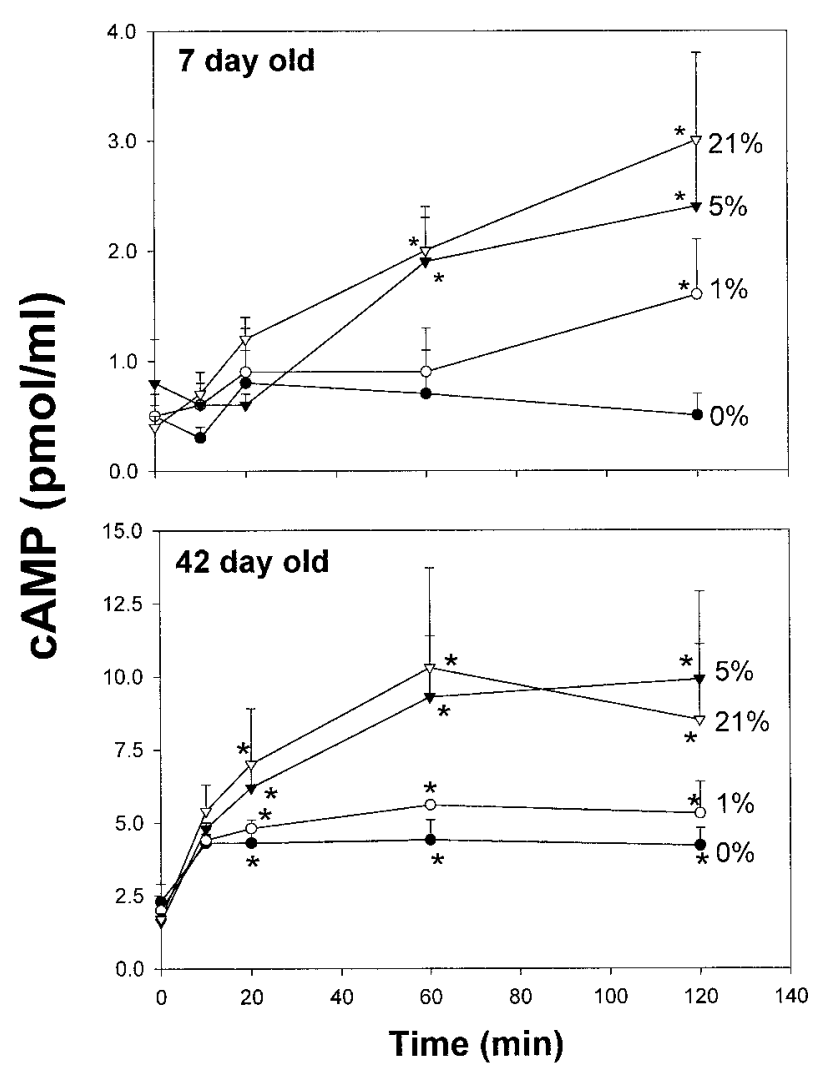

Figure 2 ACTH-stimulated cAMP production from rat ZG cells exposed to decreasing levels of $\mathrm{O}_{2}$. ACTH $(20 \mathrm{ng} / \mathrm{ml})$ was added to the cell medium at $t=0$. Vertical lines above data points represent S.E.M. *Value significantly different from basal $(0 \mathrm{~min})$ value at the corresponding $\% \mathrm{O}_{2}$ with $P<0 \cdot 05$. Four separate experiments were performed for each age group.

inhibition by decreased $\mathrm{O}_{2}$. Steroid production at $5 \% \mathrm{O}_{2}$ was not statistically different from $21 \% \mathrm{O}_{2}$. Furthermore, $1 \% \mathrm{O}_{2}$ resulted in a $35 \%$ decrease in aldosterone production, which was less inhibitory than that found in cells from suckling rats. Also worth noting is the increase in maximal aldosterone production in cells from older rats, as well as the latency in the response to ACTH with advancing age.

Figure 2 depicts ACTH-stimulated cAMP production from ZG cells from 7- and 42-day-old rats as a function of time. ZG cells from 7-day-old rats showed significant inhibition of cAMP production only at $\mathrm{O}_{2}$ levels below $5 \%$. cAMP production from cells from 42-day-old rats showed the same characteristics as the corresponding steroid production depicted in Fig 1. At 5\% $\mathrm{O}_{2}$ cAMP production was not statistically different from that at $21 \%$ $\mathrm{O}_{2}$, it then significantly decreased at $\mathrm{O}_{2}$ levels of 1 or $0 \%$. Cells from both age groups were able to mount rapid, but transient, increases in cAMP at $0 \% \mathrm{O}_{2}$, although only 42-day-old cells showed significant increases from $t=0$.
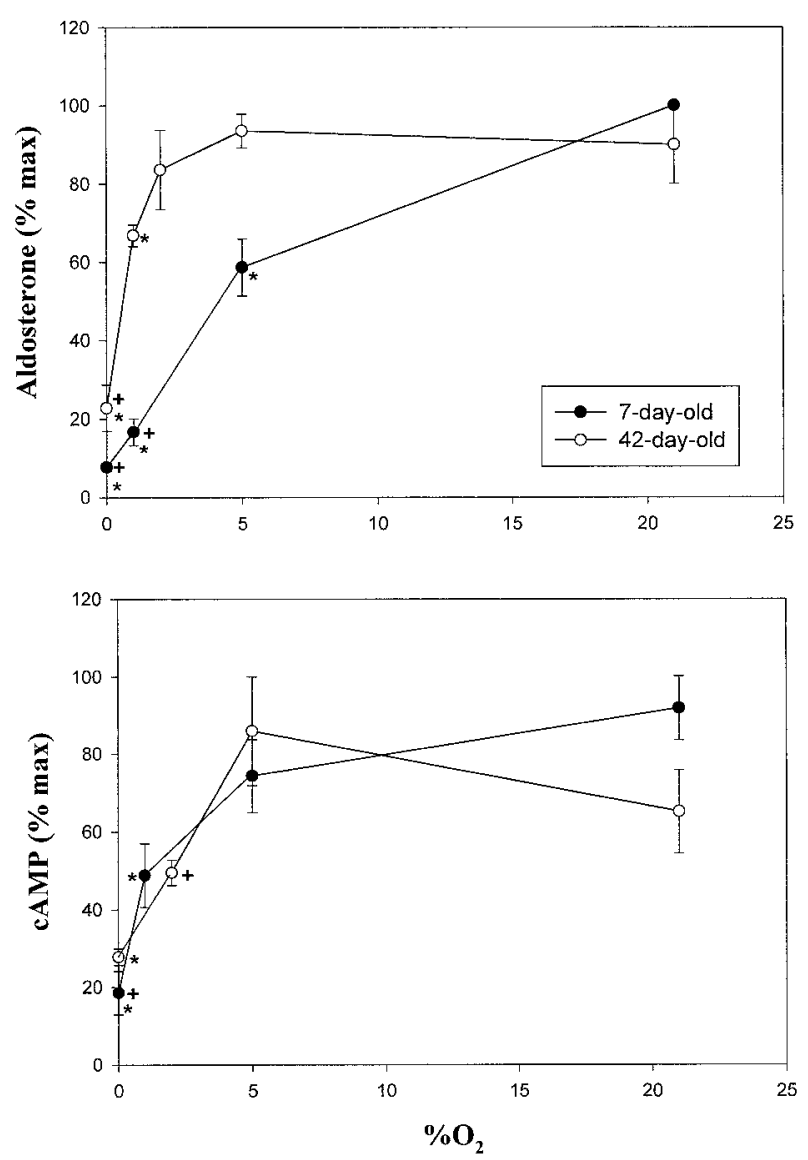

Figure $3 \mathrm{ACTH}$-stimulated aldosterone production (\% max) from rat ZG cells as a function of $\% \mathrm{O}_{2}$ (top panel). ACTH-stimulated cAMP production (\% max) from ZG cells as a function of $\% \mathrm{O}_{2}$ (bottom panel). Vertical lines above and below data points represent S.E.M. *Value significantly different from control value $\left(21 \% \mathrm{O}_{2}\right)$ for corresponding age group with $P<0 \cdot 05 .{ }^{+}$Value significantly different from value at next highest experimental $\% \mathrm{O}_{2}$ for corresponding age group, with $P<0 \cdot 05$. Four separate experiments were performed for each age group.

Results of all measurements were similar for cells from 7- and 14-day-old rats (data not shown).

Figure 3 summarizes ACTH-stimulated aldosterone and cAMP production as a function of $\% \mathrm{O}_{2}$ (data from Figs 1 and 2). Aldosterone and cAMP values were measured at the $120 \mathrm{~min}$ time point of the experiment and normalized as \% of maximum. Normalization of data was performed so that $2 \% \mathrm{O}_{2}$ experiments in 42-day-olds (additional studies) could be displayed on the same graph. The estimated $\% \mathrm{O}_{2}$ for half-maximal aldosterone production for 7- and 42-day-old rats was approximately 4\% $(\sim 28 \mathrm{mmHg})$ and $1 \% \mathrm{O}_{2}(\sim 7 \mathrm{mmHg})$ respectively. Also worth noting were the significant decreases in aldosterone production observed when values between $1 \%$ and $0 \% \mathrm{O}_{2}$ (42-day-old) and between 5\% and 1\% $\mathrm{O}_{2}$ (7-day-old) were compared. cAMP levels in 7-day-old rat cells 


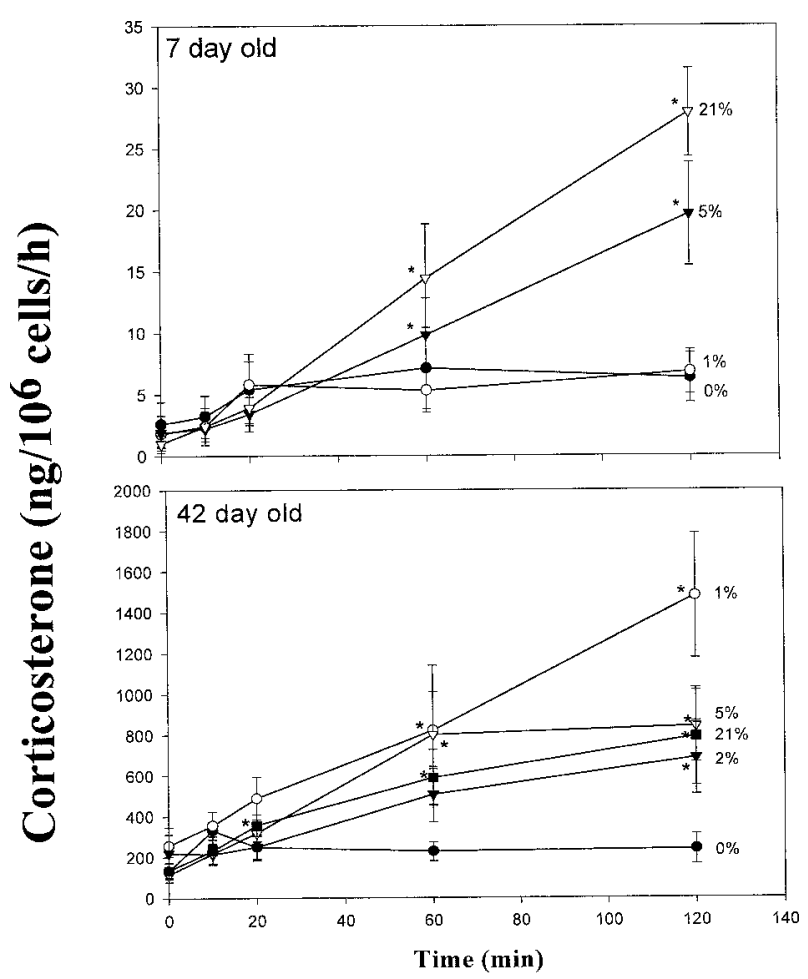

Figure $4 \mathrm{ACTH}$-stimulated corticosterone production from rat zona fasciculata/reticularis (ZFR) cells as a function of time. ACTH $(20 \mathrm{ng} / \mathrm{ml})$ was added to the cell medium at $\mathrm{t}=0$. Vertical lines above and below data points represent S.E.M. *Value significantly different from basal value $(0 \mathrm{~min})$ for the corresponding $\% \mathrm{O}_{2}$ with $P<0 \cdot 05$. Four separate experiments were performed for each age group.

decreased as the $\% \mathrm{O}_{2}$ was lowered from $21 \%$ to $5 \%$, with significant decreases from control occurring at levels below $5 \% \mathrm{O}_{2}$. cAMP levels from 42-day-old cells exhibited a similar concentration-response curve to that of aldosterone production for the same age group. The $\% \mathrm{O}_{2}$ for halfmaximal cAMP production from the $\mathrm{ZG}$ of both 7 - and 42-day-old rats was estimated at around $2 \% \mathrm{O}_{2}(\sim 14$ $\mathrm{mmHg})$. Also worth noting was the significant decrease in cAMP production between $5 \%$ and $2 \% \mathrm{O}_{2}$ (42-day-old).

Figure 4 depicts ACTH-stimulated corticosterone production from ZFR cells as a function of time. Cells from 7-day-old rats exhibited a 30\% decrease in corticosterone production at $5 \% \mathrm{O}_{2}$ and a further decrease $(80 \%)$ at $1 \%$ $\mathrm{O}_{2}$ (measured at $120 \mathrm{~min}$ ). Forty-two-day-old cells did not exhibit sensitivity to decreased $\mathrm{O}_{2}$ until $0 \% \mathrm{O}_{2}$ was reached, at which point corticosterone production was $30 \%$ of maximum. For 7-day-old cells, significant increases from $\mathrm{t}=0$ occurred only at $21 \%$ and $5 \% \mathrm{O}_{2}$. The data also illustrated the large increase in maximal steroidogenesis that occurs in older rats. Maximal values under $21 \% \mathrm{O}_{2}$ for 42-day-old cells were nearly 30 times higher than that for 7-day-old cells.

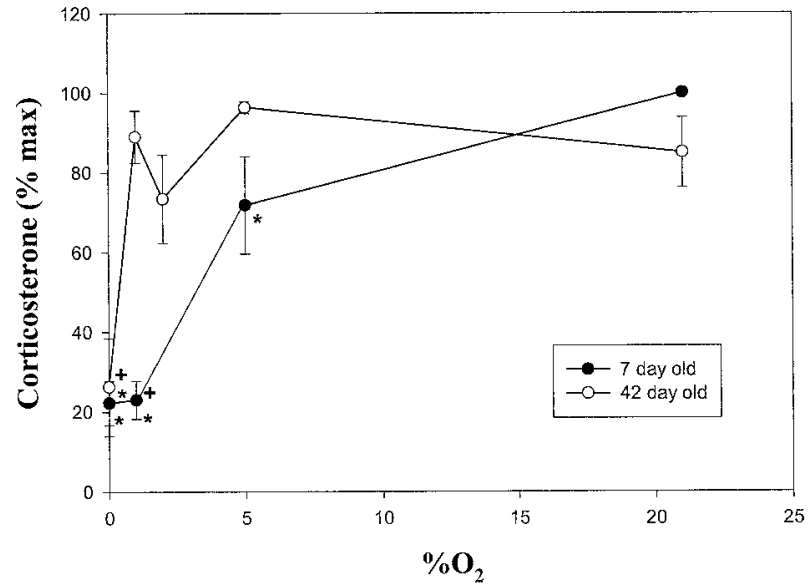

Figure 5 ACTH-stimulated corticosterone production (\% max) from ZFR cells as a function of $\% \mathrm{O}_{2}$. Vertical lines above and below data points represent S.E.M. *Value significantly different from control value $\left(21 \% \mathrm{O}_{2}\right)$ for the corresponding age group with $P<0 \cdot 05 .{ }^{+}$Value significantly different from value at next highest experimental $\% \mathrm{O}_{2}$, for corresponding age group, with $P<0 \cdot 05$. Four separate experiments were performed for each age group.

The concentration-response curve for $\% \mathrm{O}_{2}$ and corticosterone production is depicted in Fig. 5. Estimated $\% \mathrm{O}_{2}$ for half-maximal corticosterone production was $4 \% \mathrm{O}_{2}$ for 7-day-old cells and less than $1 \% \mathrm{O}_{2}$ for 42 -day-old cells. Because of a significant change by the vendor of the cAMP assay methodology, we were unable to complete cAMP measurements in subcapsule experiments from 7-day-old rats. Data from 42-day-old cells showed no significant changes in cAMP across the levels of $\mathrm{O}_{2}$ used (not shown).

Figure 6 depicts steroidogenic enzyme activity in the ZG. The top panel shows cAMP-stimulated pregnenolone production from endogenous precursors after $120 \mathrm{~min}$ incubation as a function of $\% \mathrm{O}_{2}$ (early pathway: $\mathrm{P} 450 \mathrm{scc}$ activity). ZG cells from 42-day-old rats displayed significant decreases (49\%) in P450 scc activity (as compared with that at $21 \% \mathrm{O}_{2}$ ) when $\mathrm{O}_{2}$ levels were decreased to $5 \%$ (there was no further inhibition below $5 \% \mathrm{O}_{2}$ ). P450 scc activity in 7-day-old ZG cells was significantly increased (81\%) from control at $5 \% \mathrm{O}_{2}$, and then significantly decreased (34\%) between $5 \%$ and $1 \% \mathrm{O}_{2}$. The lower panel displays the conversion of progesterone to aldosterone after $120 \mathrm{~min}$ incubation as a function of $\% \mathrm{O}_{2}$ (late pathway: P450 aldo activity). P450 aldo activity was essentially unaffected by decreases in $\mathrm{O}_{2}$ from $21 \%$ to $5 \%$ (both age groups), but decreased dramatically at lower $\mathrm{O}_{2}$ levels. The decreases in aldosterone production observed between $5 \%$ and $1 \% \mathrm{O}_{2}$ for 7 - and 42 -day-olds were $75 \%$ and $51 \%$ respectively. Early and late steroidogenic enzyme activities were also found to be higher in cells from older rats, as noted for maximal steroid output.

The assessment of P450 scc and P450c11 $\beta$ enzyme activities in the ZFR is depicted in Fig. 7. The top panel 

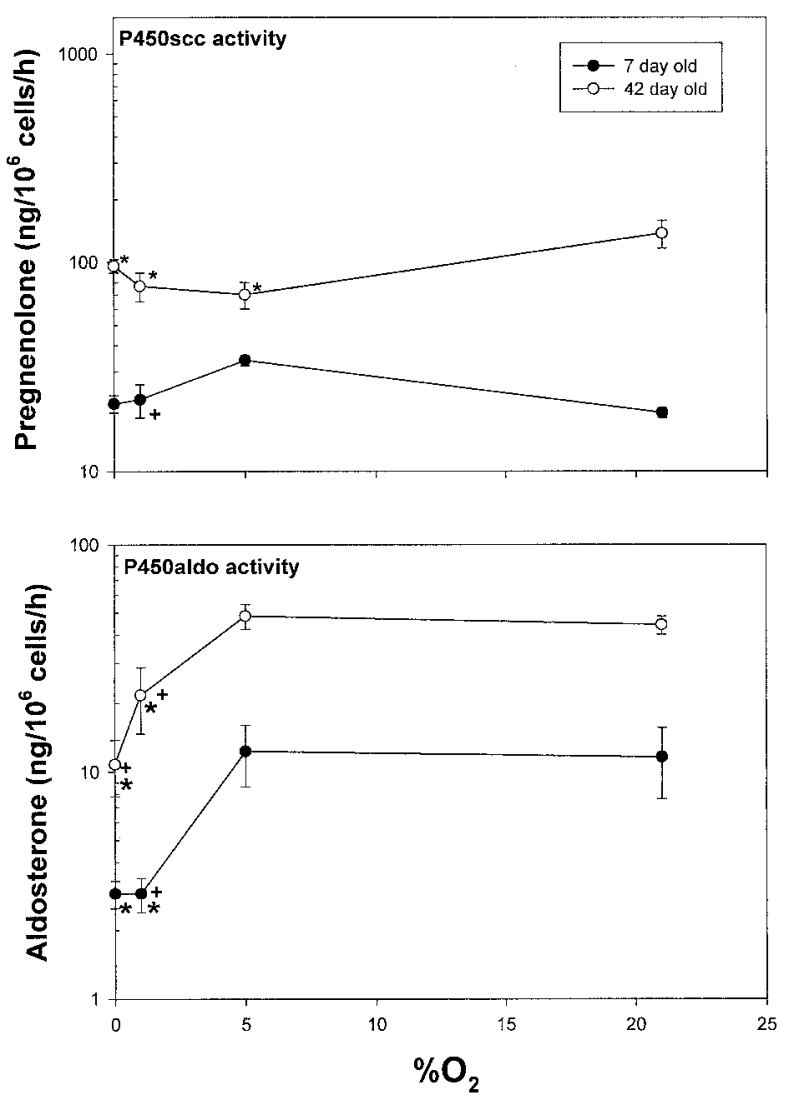

Figure 6 P450 scc (top panel) and P450 aldo (bottom panel) activities in rat ZG cells exposed to decreasing levels of $\mathrm{O}_{2}$. Vertical lines above and below data points represent S.E.M. ${ }^{*} V$ alue significantly different from control $\left(21 \% \mathrm{O}_{2}\right)$ for the corresponding age group with $P<0 \cdot 05$. Value significantly different from value at next highest experimental $\% \mathrm{O}_{2}$, for corresponding age group, with $P<0.05$. Three separate experiments were performed for each age group. The $y$-axis for each graph was log transformed to accommodate the range of data gathered from each age group.

showed significant decreases (62\%) in $\mathrm{P} 450 \mathrm{scc}$ activity in cells from 42-day-old rats at $\mathrm{O}_{2}$ levels of 5\% (as compared with $21 \% \mathrm{O}_{2}$ ). There was no further inhibition of $\mathrm{P} 450$ scc activity at levels of $\mathrm{O}_{2}$ below 5\%. P450 scc activity in 7-day-old ZFR cells showed a very similar concentrationresponse curve to that of $\mathrm{P} 450 \mathrm{scc}$ activity in the 7-day-old ZG. Activity was increased by $40 \%$ when $\mathrm{O}_{2}$ was lowered from $21 \%$ to $5 \%$, and then decreased significantly between levels of $5 \%$ and $1 \% \mathrm{O}_{2}$. The lower panel shows no significant change in $\mathrm{P} 450 \mathrm{c} 11 \beta$ activity in 42-day-old cells across the range of $\mathrm{O}_{2}$ studied. However, 7-day-old ZFR cells displayed significant decreases (38\%) in P450c11 $\beta$ activity when the $\% \mathrm{O}_{2}$ was decreased from control $(21 \%)$ to $5 \%$. There were no significant decreases in P450c11 $\beta$ at levels of $\mathrm{O}_{2}$ below $5 \%$. The lower panel also illustrates the aforementioned higher steroid production in older rats.
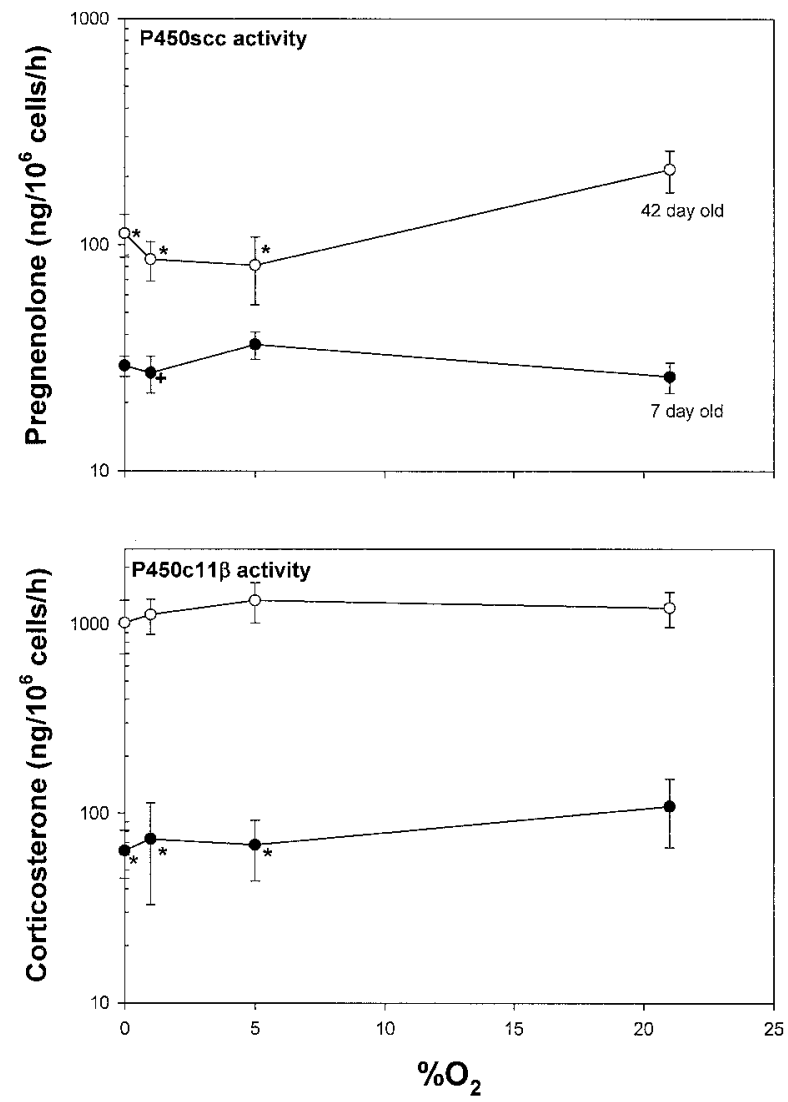

Figure 7 P450 scc (top panel) and P450c11 (bottom panel) activities in rat ZFR cells exposed to decreasing levels of $\mathrm{O}_{2}$. Vertical lines above and below data points represent S.E.M. ${ }^{*}$ Value significantly different from control $\left(21 \% \mathrm{O}_{2}\right)$ for the corresponding age group with $P<0.05$. Three separate experiments were performed for each age group. The $y$-axis for each graph was log transformed to accommodate the range of data gathered from each age group.

P450c11 $\beta$ activity was nearly an order of magnitude higher in cells from 42-day-old rats when compared with that of 7-day-old rats.

Table 1 shows basal (no ACTH) aldosterone levels at the 120 min time point of the experimental incubation. Significant changes in basal aldosterone were observed in ZG cells only when $0 \% \mathrm{O}_{2}$ was reached. This was true for cells at all three ages. The table also illustrates an increase in basal aldosterone production with advancing age.

Initial cell viabilities $\left(10^{6} \mathrm{cell} / \mathrm{ml}\right)$ ranged from $2 \cdot 8$ to $4 \cdot 0$, with increased cell concentration observed in ZFR preparations as well as in preparations from older rats. There was no significant decrease in cell viability following a $2 \mathrm{~h}$ exposure to $0 \% \mathrm{O}_{2}$ regardless of age, cell type, or treatment (data not shown). 
Table 1 Basal aldosterone production ( $\mathrm{ng} / 10^{6}$ cells per $\mathrm{h}$ ) at 120 min of incubation

\begin{tabular}{|c|c|c|c|}
\hline & Age (days) & & \\
\hline & 7 & 14 & 42 \\
\hline$\% \mathrm{O}_{2}$ & & & \\
\hline 0 & $1 \cdot 6 \pm 0.5^{*}$ & $2 \cdot 4 \pm 0 \cdot 5^{*}$ & $22 \cdot 4 \pm 4 \cdot 6^{*}$ \\
\hline 1 & $3 \cdot 1 \pm 0 \cdot 7$ & $5 \cdot 5 \pm 1 \cdot 3$ & $52 \cdot 7 \pm 27 \cdot 6$ \\
\hline 5 & $4 \cdot 1 \pm 1 \cdot 0$ & $7 \cdot 4 \pm 1 \cdot 3$ & $132 \cdot 0 \pm 43 \cdot 9$ \\
\hline 21 & $5 \cdot 1 \pm 1 \cdot 1$ & $6 \cdot 6 \pm 1 \cdot 0$ & $88 \cdot 4 \pm 31 \cdot 5$ \\
\hline
\end{tabular}

Basal aldosterone production (no ACTH) from zona glomerulosa (ZG) cells following $120 \mathrm{~min}$ of incubation at $37^{\circ} \mathrm{C}$ as a function of $\mathrm{O}_{2}$. Results are given as the mean \pm S.E.M. *Value significantly decreased from control $\left(21 \% \mathrm{O}_{2}\right)$ for that corresponding age group. Four separate experiments were performed for each age group.

\section{Discussion}

The purpose of this study was to determine the effects of decreasing $\mathrm{O}_{2}$ concentrations on steroidogenesis from rat adrenocortical cells in vitro. Previous studies examined the effects of hypoxia on steroidogenesis in a variety of species (Raff 1991, Brickner et al. 1992, Raff et al. 1996, Raff et al. 1999). We chose to study adrenal cells from rats at two distinct stages of development. Most previous studies have examined the effects of hypoxia on steroidogenesis in vivo (Raff \& Chadwick 1986, Raff et al. 1986, Raff et al. 1999). We wanted to examine the effects of acute hypoxia in vitro and compare them with results previously found for bovine cells (Raff \& Kohandarvish 1990, Brickner et al. 1992). The cellular mechanisms involved in ACTHstimulated steroidogenesis were given close attention.

\section{Acute decreases in $\mathrm{O}_{2}$ and the zona glomerulosa}

These studies found ACTH-stimulated steroid production from rat adrenocortical cells to be decreased when cells were subjected to decreased $\mathrm{O}_{2}$ concentrations. This effect was most pronounced in the ZG of both 7- and 42-dayold rats, a zonal specificity that has been shown experimentally to exist in both adult humans and adult rodents (Slater et al. 1969, Raff 1991). Aldosterone production was greatly inhibited in cells from 7-day-old rats as compared with those of 42-day-olds.

These initial findings clearly indicated that the rat $Z G$, regardless of age, is much more resistant to hypoxia than the bovine $\mathrm{ZG}$. Estimated $\mathrm{P}_{50}$ values for aldosterone production were $28 \mathrm{mmHg}$ for 7 -day-old and $7 \mathrm{mmHg}$ for 42-day-old rat cells. These values are quite remarkable when compared with the $\mathrm{P}_{50}$ obtained for bovine cells, estimated to be around $95 \mathrm{mmHg}\left(\sim 13 \% \mathrm{O}_{2}\right)$ (Raff \& Kohandarvish 1990). This difference is not surprising considering the significant difference between these two species in the control of steroidogenesis and enzyme expression (Muller 1991).
cAMP has long been known to be the main second messenger involved in ACTH-stimulated aldosterone production (Haynes 1958, Cote et al. 1999). The accumulation of cAMP in the cell medium was measured following ACTH-stimulation under varying levels of $\mathrm{O}_{2}$, and these values were used as an index of cAMP generation (Matthys et al. 1998). ACTH-stimulated aldosterone production from 7-day-old ZG cells was significantly decreased at levels of $\mathrm{O}_{2}$ below 21\%. This could be partially explained by changes in cAMP generation. ACTH-stimulated cAMP production from 7-day-old cells was not significantly decreased (from control) until cells were exposed to $1 \% \mathrm{O}_{2}$. Significant decreases in aldosterone production from 42 -day-old cells did not occur until the concentration of $\mathrm{O}_{2}$ was lowered to $1 \%$. cAMP production from 42-day-old ZG cells was significantly decreased at $2 \% \mathrm{O}_{2}$. Therefore, decreases in cAMP could be at least partially responsible for the observed decreases in aldosterone production.

It was of interest to determine if the early pathway (including cholesterol transport) was affected by hypoxia, independent of any observed changes in cAMP (Papadopoulos et al. 1997, Stocco \& Clark 1997, Zilz et al. 1999). It would seem that the decreases in aldosterone production observed between $5 \%$ and $1 \% \mathrm{O}_{2}$ (7-day-old ZG) could be explained by decreased P450 scc activity, decreased cholesterol delivery, or a combination of both. Previous research lends support to the idea that the $\mathrm{O}_{2}$-dependence of $\mathrm{P} 450 \mathrm{scc}$ is actually due to a reduction in cholesterol delivery under hypoxic conditions (Stevens et al. 1984). Future experiments using permeable forms of cholesterol as a substrate will provide answers regarding isolated activity of P450 scc.

Previous bovine studies performed in vitro found that low $\mathrm{O}_{2}$ specifically inhibited the late pathway P450 aldo (Brickner et al. 1992). Other studies using bovine cells found that the activity of another cytochrome enzyme, $\mathrm{P} 450 \mathrm{c} 17 \alpha$, was also sensitive to decreases in $\mathrm{O}_{2}$ (Chabre et al. 1993). Our results showed significant decreases in P450 aldo activity at $\mathrm{O}_{2}$ levels below 5\% (both age groups). Therefore, in ZG cells from 42-day-old rats, decreased aldosterone production under acute hypoxia could be attributed to decreased P450 aldo activity, as shown for bovine cells. Decreases in aldosterone production from 7-day-old ZG cells under low $\mathrm{O}_{2}$ could be explained, at least partially, by decreased P450 aldo activity.

Our results indicate that aldosterone production from 42-day-old ZG cells is inhibited only by severe decreases in $\mathrm{O}_{2}$. This inhibition seems to take place at the level of P450 aldo, and the decrease in P450 aldo activity could be due to the direct inhibition of P450 aldo. Reduced substrate availability could be due to decreases in molecular $\mathrm{O}_{2}$ or a reduction in equivalent generation via the respiratory chain (NADH). However, these mechanisms of inhibition may not be the only explanations for the 
observed decreases in P450 aldo activity. An alternative explanation could be that $\mathrm{P} 450$ aldo activity was inhibited by increased release of nitric oxide (NO) (Hanke \& Campbell 2000).

What mechanisms could explain the decrease in aldosterone production observed in 7-day-old cells as $\mathrm{O}_{2}$ was lowered from $21 \%$ to $5 \%$ ? Although the results seem to indicate that decreased cAMP production was responsible for this decrease, it has been shown that ACTH-stimulated steroid production in the rat ZG may depend on non-cAMP mechanisms (Gallo-Payet et al. 1999). These include such mechanisms as the phospholipase $\mathrm{C}$ /protein kinase $\mathrm{C}$ pathway and related intracellular fluxes in $\mathrm{Ca}^{2+}$ concentration (Durroux et al. 1991, Gallo-Payet et al. 1996, Gallo-Payet et al. 1999). It is possible that hypoxia alters the response of these separate signaling pathways to ACTH. Likewise, changes in mitochondrial function and/or properties may also play a role in decreased ACTH-stimulated aldosterone production during acute hypoxia. Previous studies utilizing rabbit kidney tubule cells found that hypoxia caused a change in mitochondrial electrochemical gradient (designated $\Psi_{\mathrm{m}}$ ) induced by decreases in aerobic respiration (Weinberg et al. 2000). These findings would lend support to other studies that found that the delivery of cholesterol (via steroidogenic acute regulatory protein (StAR)) to the inner mitochondrial membrane was dependent on an intact $\Psi_{\mathrm{m}}$ (King et al. 1999).

\section{Acute decreases in $\mathrm{O}_{2}$ and the zona fasciculata/reticularis}

ACTH-stimulated corticosterone production from 7-dayold ZFR cells was affected by decreased $\mathrm{O}_{2}$ in a concentration-dependent manner. The $\mathrm{P}_{50}$ for ACTHstimulated corticosterone production from 7-day-old cells was approximately $28 \mathrm{mmHg}$. The corticosterone response of 7-day-old ZFR cells to ACTH stimulation under decreasing levels of $\mathrm{O}_{2}$ was quite similar to the aldosterone response of 7-day-old ZG cells. Forty-two-day old ZFR cells were by far the most resistant to inhibition of ACTH-stimulated steroidogenesis by decreased $\mathrm{O}_{2}$. The $\mathrm{P}_{50}$ for corticosterone production in 42-day-old ZFR cells was actually less than $7 \mathrm{mmHg}$. When ACTHstimulated cAMP production from 42-day-old ZFR cells was assessed, results indicated no significant changes across the range of $\mathrm{O}_{2}$ studied.

The concentration-response curves for $\mathrm{P} 450 \mathrm{scc}$ activity (early pathway) and $\% \mathrm{O}_{2}$ in $\mathrm{ZFR}$ cells were similar to the curves found for ZG cells (both age groups). Given these findings, it is likely that changes in ZFR P450 scc activity due to hypoxia are at least partly responsible for the decrease in corticosterone production observed between $5 \%$ and $1 \% \mathrm{O}_{2}$ (7-day-old cells). The activity of $\mathrm{P} 450 \mathrm{c} 11 \beta$ in ZFR cells was only slightly affected by decreases in $\mathrm{O}_{2}$. $\mathrm{P} 450 \mathrm{c} 11 \beta$ activity in 7-day-old cells was significantly decreased (38\%) when the $\% \mathrm{O}_{2}$ was lowered from $21 \%$ to
$5 \%$. However, further decreases in $\mathrm{O}_{2}$ to levels approaching $0 \%$ had no significant effect on P450c11 $\beta$ activity in these neonatal cells.

The effect of acute hypoxia on ZFR cells shows similarities to its effect on aldosterone production from ZG cells, but the mechanisms differ slightly. The effects of decreased $\mathrm{O}_{2}$ on 7-day-old ZFR corticosterone production could be partially explained by decreases in P450c11 $\beta$ activity (between 21\% and 5\% $\mathrm{O}_{2}$ ) and decreases in P450 scc activity (between $5 \%$ and $1 \% \mathrm{O}_{2}$ ). But, as with findings for $\mathrm{ZG}$ cells, decreases in enzyme activity must be explained further (e.g. $\mathrm{NO}$ and mitochondrial alterations). A study examining the effects of $\mathrm{NO}$ on rat ZFR cells found that increases in intracellular NO production specifically inhibited corticosterone production by decreasing the activity of P450 scc (Cymeryng et al. 1998). However, as stated earlier, a decrease in $\mathrm{P} 450 \mathrm{scc}$ activity may not necessarily be due to a direct effect of low $\mathrm{O}_{2}$ on the enzyme itself.

One possible explanation could be an alteration in StAR activity under hypoxia. Previous research performed in vivo has shown that acute increases in corticosterone production (1-2 h post-ACTH stimulation) may be due to small, but significant, increases in StAR activity (Lehoux et al. 1999). The findings indicated the presence of multiple isoforms of the StAR protein, each having a unique isoelectric point (pI). It could be possible that some cellular effect of hypoxia, perhaps small changes in $\mathrm{pH}$, overrides the stimulatory action of ACTH on StARmediated cholesterol transport. This inhibition could depend on the StAR isoforms present in the cell, and could be hypothesized to occur in ZG cells as well as in ZFR cells.

The observed decreases in corticosterone production from 7-day-old cells could also be explained by changes in $\mathrm{Ca}^{2+}$ dynamics, as mentioned earlier with regards to the ZG. Previous research has shown that calcium channel blocking agents, such as verapamil, significantly decreased both ACTH and cAMP-stimulated corticosterone production (Matsuki et al. 1996). The stimulatory and permissive actions of intracellular $\mathrm{Ca}^{2+}$ have been very well established (Mahaffee \& Ontjes 1980, Cheitlin et al. 1985, Ganguly \& Davis 1994, Gallo-Payet et al. 1996) and inhibitory properties of $\mathrm{Ca}^{2+}$ have been proposed as well (Cooper et al. 1995). Most of these studies found a strong interaction between $\mathrm{Ca}^{2+}$ and cAMP.

Decreases in corticosterone production in ZFR cells from 42-day-old rats did not occur until the level of $\mathrm{O}_{2}$ approached $0 \%$. This occurred without significant changes in enzyme activities or cAMP dynamics. What could be a possible explanation for this decrease in corticosterone production? Perhaps at such low $\mathrm{O}_{2}$ tension the cells simply do not survive or have severely diminished function. The fact that cell viability was not significantly altered after $2 \mathrm{~h}$ under $0 \% \mathrm{O}_{2}$ argues against the former. Although there was no significant decrease in P450c11 $\beta$ 
activity to explain the decreased corticosterone production (at $0 \% \mathrm{O}_{2}$ ), the fact that its activity was studied in the presence of excess substrate (progesterone) could explain the discrepancy. Previous research studying the effects of hypoxia on placental villi found that the activity of $3 \beta$-HSD was reduced under low $\mathrm{O}_{2}$ (Gabbe \& Villee 1971). Therefore, the decreased corticosterone production from 42-day-old ZFR cells at $0 \% \mathrm{O}_{2}$ may be due to $3 \beta-\mathrm{HSD}$ inhibition by low $\mathrm{O}_{2}$.

How does the stress hyporesponsive period (SHP) relate to the present study? Adrenocortical cells from 7-day-old rats, when exposed to decreasing $\mathrm{O}_{2}$, showed similar dose-dependent decreases in ACTH-stimulated aldosterone and corticosterone production. Since the same concentration of ACTH was used across all levels of $\mathrm{O}_{2}$ studied, it provides evidence that hypoxia further decreases responsiveness to ACTH through the aforementioned mechanisms. Decreased P450 scc activity in neonatal cells at low levels of $\mathrm{O}_{2}(<5 \%)$ may be augmented by the decreases in peripheral-type benzodiazepine receptor (PBR) expression (reduced cholesterol transport) normally found at this age (Zilz et al. 1999). It is also possible that hypoxia indirectly affects PBR activity, independently of gene expression (e.g. $\mathrm{Ca}^{2+}$ flux).

\section{Theoretical interpretation of the results}

The concentration of $\mathrm{O}_{2}$ present in the atmosphere $(21 \%$ $\mathrm{O}_{2} ; \sim 150 \mathrm{mmHg}$ ) was used as a control. Other in vitro studies have also used this $\mathrm{O}_{2}$ concentration as a control (Raff et al. 1989, Brickner et al. 1992, Raff \& Jankowski 1995). However, the $\mathrm{PO}_{2}$ of arterial blood is $\sim 95 \mathrm{mmHg}$ (Raff et al. 1986). Studies performed in normoxic dogs determined the $\mathrm{PO}_{2}$ of adrenal venous blood to be $\sim 70$ $\mathrm{mmHg}$ (Breslow et al. 1990). Since venous $\mathrm{PO}_{2}$ reflects capillary $\mathrm{PO}_{2}$, it may be more relevant to consider a concentration of about $10 \% \mathrm{O}_{2}(\sim 70 \mathrm{mmHg})$ as a control value when studying cells in vitro. The large gap in $\mathrm{O}_{2}$ concentrations used in the current experiments (between $5 \%$ and $21 \% \mathrm{O}_{2}$ ) preclude any comparisons using $10 \% \mathrm{O}_{2}$ as a control.

There is always controversy concerning whether $\mathrm{PO}_{2}$ values used in in vitro studies represent physiologically relevant $\mathrm{O}_{2}$ levels (Jones \& Kennedy 1982). Although adrenal venous $\mathrm{PO}_{2}$ in the normoxic animal is probably higher than the mixed venous $\mathrm{PO}_{2}$, it is not clear what it is in hypoxic animals when arterial $\mathrm{PO}_{2}$ is $<40 \mathrm{mmHg}$. Adrenal venous $\mathrm{PO}_{2}$ was measured, but not explicitly reported, in a previous study of hypoxic dogs (Breslow et al. 1989); we were nevertheless able to estimate that it was $<10-20 \mathrm{mmHg}$ based on reported adrenal blood flow and oxygen extraction. Therefore, the oxygen levels in the present study may be quite representative of venous and hence capillary $\mathrm{PO}_{2}$ in the adrenal gland in vivo during hypoxia.
In addition, the $\mathrm{PO}_{2}$ at the mitochondria is unknown for adrenocortical cells. However, for other tissues, it may be as low as $1 \mathrm{mmHg}$ or even lower (Jones \& Kennedy 1982). Therefore, it may be that the $\mathrm{P}_{50}$ for steroidogenesis in bovine $\mathrm{ZG}$ cells in vitro is unusually high and that a $\mathrm{P}_{50}$ $<10 \mathrm{mmHg}$ in the rat, as we have reported here, is a better representation of mitochondrial $\mathrm{PO}_{2}$ in other mammalian adrenal glands. Regardless, it is clear that there is a developmental change in the sensitivity of adrenocortical cells to hypoxia with age that is worth pursuing.

\section{Acknowledgements}

The authors would like to thank Barbara M Jankowski for her expert technical assistance.

\section{References}

Breslow MJ, Ball TD, Miller CF, Raff H, Traystman RJ 1989 Adrenal blood flow and secretory relationships during hypoxia in anesthetized dogs. American Journal of Physiology 257 H1458-H1465.

Breslow MJ, Tobin JR, Mandrell TD, Racusen LC, Raff H \& Traystman RJ 1990 Changes in adrenal oxygen consumption during catecholamine secretion in anesthetized dogs. American Journal of Physiology 259 H681-H688.

Brickner RC, Jankowski BM \& Raff H 1992 The conversion of corticosterone to aldosterone is the site of oxygen sensitivity of the bovine adrenal zona glomerulosa. Endocrinology 130 88-92.

Chabre O, Defaye G \& Chambaz EM 1993 Oxygen availability as a regulatory factor of androgen synthesis by adrenocortical cells. Endocrinology 132 255-260.

Cheitlin R, Buckley DI \& Ramachandran J 1985 The role of extracellular calcium in corticotropin-stimulated steroidogenesis. Journal of Biological Chemistry 260 5323-5327.

Cooper DMF, Mons N \& Karpen JW 1995 Adenylyl cyclases and the interaction between calcium and cAMP signaling. Nature $\mathbf{3 7 4}$ 421-424

Cote M, Payet MD, Rosseau E, Guillon G \& Gallo-Payet N 1999 Comparative involvement of cyclic nucleotide phosphodiesterases and adenylyl cyclase on ACTH-induced increase of cAMP in rat and human glomerulosa cells. Endocrinology 140 3594-3601.

Cymeryng CB, Dada LA \& Podesta EJ 1998 Effect of nitric oxide on rat adrenal zona fasciculata steroidogenesis. Journal of Endocrinology 158 197-203.

Durroux T, Gallo-Payet N \& Payet MD 1991 Effects of ACTH on action potential and calcium currents in cultured rat and bovine glomerulosa cells. Endocrinology 129 2139-2147.

Elliot MB \& Goodfriend TL 1986 Inhibition of aldosterone synthesis by atrial natriuretic factor. Federation Proceedings 45 2376-2381.

Feuillan PP \& Aguilera G 1996 Regulation of aldosterone in the 7-day-old rat. Endocrinology 137 3992-3998.

Friedman AH \& Fahey JT 1993 The transition from fetal to neonatal circulation: normal responses and implications for infants with heart disease. Seminars in Perinatalogy 17 106-121.

Gabbe SG \& Villee CA 1971 The effect of hypoxia on progesterone synthesis by placental villi in organ culture. American Journal of Obstetrics and Gynecology 111 31-37.

Gallo-Payet N, Grazzini E, Cote M, Chouinard L, Chorvatova A, Bilodeau L, Payet MD \& Guillon G 1996 Role of $\mathrm{Ca}^{2+}$ in the action of ACTH in cultured human adrenal glomerulosa cells. Journal of Clinical Investigation 98 460-466. 
Gallo-Payet N, Cote M, Chorvatova A, Guillon G \& Payet MD 1999 Cyclic-AMP independent effects of ACTH on zona glomerulosa cells of the rat adrenal cortex. Journal of Steroid Biochemistry and Molecular Biology 69 335-342.

Ganguly A \& Davis JS 1994 Role of calcium and other mediators in aldosterone secretion from the adrenal glomerulosa cells. Pharmacological Reviews 46 417-447.

Hanke CJ \& Campbell WB 2000 Endothelial cell nitric oxide inhibits aldosterone synthesis in zona glomerulosa cells: modulation by oxygen. American Journal of Physiology: Endocrinology and Metabolism 279 E846-E854.

Haynes RC 1958 The activation of adrenal phosphorylase by the adrenocorticotropic hormone. Journal of Biological Chemistry 233 1220-1223.

Jones DP \& Kennedy FG 1982 Intracellular oxygen supply during hypoxia. American Journal of Physiology 243 C247-C253.

King SR, Liu Z, Soh J, Eimer S, Orly J \& Stocco DM 1999 Effects of mitochondrial electrochemical gradient on steroidogenesis and the steroidogenic acute regulatory (StAR) protein. Journal of Steroid Biochemistry and Molecular Biology 69 143-154.

Lehoux JG, Hales DB, Fleury A, Briere N, Martel D \& Ducharme L 1999 The in vivo effects of adrenocorticotropin and sodium restriction on the formation of different species of steroidogenic acute regulatory protein in rat adrenal. Endocrinology $\mathbf{1 4 0}$ $5154-5164$.

Mahaffee DD \& Ontjes DA 1980 The role of calcium in the control of adrenal adenylate cyclase: enhancement of enzyme activation by guanyl-5'-yl imidodiphosphate. Journal of Biological Chemistry 255 1565-1571.

Matsuki M, Watanabe S, Ikeda S \& Saito T 1996 Effects of calcium channel blockers on steroidogenesis stimulated by ACTH and cAMP in isolated rat adrenal cells. Hormone and Metabolic Research 28 374-376.

Matthys L, Castello R, Zilz A \& Widmaier EP 1998 Different sensitivity to ACTH, but not stress, in two sources of outbred Sprague-Dawley rats. Neuroendocrinology 184 1-9.

Muller J 1991 Aldosterone biosynthesis in bovine, rat and human adrenal: commonalities and challenges. Molecular and Cellular Endocrinology 78 C119-C124.

Papadopoulos V, Amri H, Boujrad N, Cascio C, Culty M, Garnier M, Hardwick M, Li H, Vidic B, Brown AS, Reversa JL \& Drieu K 1997 Peripheral benzodiazepine receptor in cholesterol transport and steroidogenesis. Steroids 62 21-28.

Raff H 1991 The renin-angiotensin-aldosterone system during hypoxia. In Response and Adaptation to Hypoxia-Organ to Organelle, pp 211-222. Eds S Lahiri, N Cherniak \& RS Fitzgerald. New York: Oxford University Press.

Raff H \& Chadwick CJ 1986 Aldosterone responses to ACTH during hypoxia in conscious rats. Clinical and Experimental Pharmacology and Physiology 13 827-830.

Raff H \& Roarty TP 1988 Renin, ACTH, and aldosterone during acute hypercapnia and hypoxia in conscious rats. American Journal of Physiology: Regulatory, Integrative, and Comparative Physiology 254 R431-R435.
Raff H \& Kohandarvish S 1990 The effect of oxygen on aldosterone release from bovine adrenocortical cells in vitro: $\mathrm{PO}_{2}$ vs. steroidogenesis. Endocrinology 127 682-687.

Raff H \& Jankowski BM $1995 \mathrm{O}_{2}$ dependence of pregnenolone and aldosterone synthesis in mitochondria from bovine zona glomerulosa cells. Journal of Applied Physiology 78 1625-1629.

Raff H, Sandri RB \& Segerson TP 1986 Renin, ACTH, and adrenocortical function during hypoxia and hemorrhage in conscious rats. American Journal of Physiology: Regulatory, Integrative, and Comparative Physiology 250 R240-R244.

Raff H, Ball DL \& Goodfriend TL 1989 Low oxygen selectively inhibits aldosterone secretion from bovine adrenocortical cells in vitro. American Journal of Phyisology: Endocrinology and Metabolism 256 E640-E644.

Raff H, Jankowski BM, Engeland WC \& Oaks MK 1996 Hypoxia in vivo inhibits aldosterone synthesis and aldosterone synthase mRNA in rats. Journal of Applied Physiology 81 604-610.

Raff H, Jankowski BM, Bruder ED, Engeland WC \& Oaks MK 1999 The effect of hypoxia from birth on the regulation of aldosterone in the 7-day-old rat: plasma hormones, steroidogenesis in vitro, and steroidogenic enzyme mRNA. Endocrinology $1403147-3153$.

Slater JDH, Tuffley RE, Williams ES, Beresford CH, Sonksen PH, Edwards RH, Ekins RP \& McLaughlin M 1969 Control of aldosterone secretion during acclimatization to hypoxia in man. Clinical Science 37 327-341.

Stevens VL, Aw TY, Jones DP \& Lambeth JD 1984 Oxygen dependence of adrenal cortex cholesterol side chain cleavage. Journal of Biological Chemistry 259 1174-1179.

Stocco DM \& Clark BJ 1997 The role of the steroidogenic acute regulatory protein in steroidogenesis. Steroids 62 29-36.

Thomas JT \& Marshall JM 1995 A study on rats of the effects of chronic hypoxia from birth on respiratory and cardiovascular responses evoked by acute hypoxia. Journal of Physiology (London) $487513-525$

Walker CD, Perrin M, Vale W \& Rivier C 1986 Ontogeny of the stress response in the rat: role of the pituitary and hypothalamus. Endocrinology 118 1445-1451.

Walker CD, Scribner KA, Cascio CS \& Dallman MF 1991 The pituitary adrenocortical system of neonatal rats is responsive to stress throughout development in a time-dependent and stressor-specific fashion. Endocrinology 128 1385-1395.

Weinberg JM, Venkatachalam MA, Roeser NF \& Nissim I 2000 Mitochondrial dysfunction during hypoxia/reoxygenation and its correction by anaerobic metabolism of citric acid cycle intermediates. PNAS 97 2826-2831.

Zilz A, Li H, Castello R, Papadopoulos V \& Widmaier EP 1999 Developmental expression of the peripheral-type benzodiazepine receptor and the advent of steroidogenesis in rat adrenal glands. Endocrinology 140 859-864.

Received 22 October 2001

Accepted 12 November 2001 